GABOR LUX

Hungarian Academy of Sciences - Centre for Regional Studies, Pécs

\title{
Location differences of services and industry: A Central European dichotomy
}

\section{INTRODUCTION}

In post-socialist spatial restructuring, over-industrialised economies experienced a period of intense tertiarisation and the decline of industrial employment. However, the role of industry and services in this process shows strong sectoral and spatial differences: their contribution to economic development and social modernisation are not equally distributed. While advanced business services are strongly concentrated in central regions, a high share of tertiary employment elsewhere may be a sign of economic deterioration and a lack of economic alternatives: meanwhile, outside metropolitan areas, growth is still mainly driven by industrial activities - mainly where FDI-based manufacturing is located.

This paper examines how the tertiarisation process since 1990 has affected Central European space, and how the dichotomy of services and industry contributes to spatial structures, where a differentiation process between north-western and south-eastern states, as well as central and non-central regions can be observed, recreating, and where they already existed, reinforcing traditional divides.

The main metric of this paper is employment. While differences between resourceintensive, labour-intensive, scale-intensive, specialised supplier and science-based industries (as discussed in Guerrieri, 1998 and Soós Károly, 2002) are relevant to post-socialist development processes, there are clear advantages to using employment figures: first, the availability of up-to-date cross-sectional data enables a broader comparison; second, as the paper's results show, a number of traditional industrial branches still contribute to growth on the EU's eastern and south-eastern peripheries.

\section{THE INITIAL CONDITIONS OF POST-SOCIALIST RESTRUCTURING}

At the point of systematic change, the states of Central Europe had already been facing a severe transformation recession. The initial conditions of economic restructuring were, therefore, characterised by the need to cope with both the legacy of socialism and the new dilemmas of transition. 
First, the newly democratic states inherited a collection of untreated, postponed crises from state socialism; recession had already been severe in all economic branches, but especially striking in industry. The industrial crisis was often considered a systematic problem: Winiecki (1986) supplied comprehensive data about the tendency of socialist states to over-industrialise at the cost of more advanced service activities; in a seminal article, Kornai (1993) considers the decline of industry a component of structural change in transformation recession. These points are, however, debatable: symptoms of industrial decline were not unique to socialist economies; the Old Industrial Region problem (discussed, among others, by Steiner, 1985, Grabher, 1993 and Hudson, 1994) had lead to severe depression in Western Europe's traditional industrial heartlands two decades before 1990. The symptoms and causes, if not entirely identical, are strikingly similar, from over-specialisation and rigid industrial monostructures to network - and agglomeration-related problems. Furthermore, unlike the other components of Kornai's transformation recession (transiting from a seller-driven to a buyer-driven market, disruptions in economic coordination, the hardening of budget constraints, and the backwardness of the financial sector), the transformation of the real structure of the economy, and within it industrial transformation, has been a much more protracted and much more painful process. Therefore, it appears best to speak of the effects of two parallel but separate phenomena: on one hand the systematic failure of state socialism, and on the other hand the global shift towards post-industrial economies, where the transformation of post-socialist economies is more delayed than specific to post-socialism.

The second condition of restructuring was tied to the weakness of the new market economies: while the previous structures of socialism had been radically weakened, neither private nor public capital was available to finance an effective, comprehensive restructuring effort. In particular, the public sector was struggling with inadequate financial resources, and in some cases, high foreign debt; additionally, political capital was also lacking - due in part to the spectacular economic and environmental failures of socialist industrialisation, but also the general political, intellectual and civic criticism of public planning as a failed institution.

Finally, the third condition was related to the institutional instability of transition: confronting a chaotic and fast-changing environment, the public sector could not keep up with the changes let alone manage them; in the absence of radical planning (i.e. the fusion of planning, decision-making and execution; Faragó, 2004) and a functional system to take incrementalist steps, the prevention of social catastrophe (wholesale economic collapse) at the cost of further crisis postponement and a growth penalty (Audretsch et al, 2000) was coupled with basically laissez-faire, market-oriented solutions.

\section{THE UNEVEN CONSEQUENCES OF RESTRUCTURING}

As a consequence of the aforementioned conditions, restructuring was predominantly passive and market-driven; public intervention focussed on the prevention of complete failure in certain priority areas (often mining and metallurgical centres), while economic duality, or wide disparities between companies, branches and regions with a high versus low penetration of Foreign Direct Investment became visible. The main characteristic of economic restructuring was tertiarisation, transformation to mainly service-based economies. 
Industrial production and employment was worst hit by immediate transformation recession in all Central European post-socialist states except Hungary (where it was agriculture); concurrently, services were, and are still considered a panacea to the ills of both socialist failure and traditional underdevelopment.

However, the process of tertiarisation should be understood as not only ubiquitous, but also both generally and spatially uneven: the results are divergent, giving rise to new and recreating old central-periphery arrangements. In general, tertiarisation can be seen as a vital process of structural correction, bringing Winiecki's over-industrialised economies in line with European trends, and also allowing the rise of consumption and business services, which were kept artificially depressed by the bureaucratic coordination of socialism. From this perspective, tertiarisation is the success of normality over an unnatural and anti-democratic situation.

Tertiarisation also serves as a modernisation process - the spread of new service functions in the post-industrial economy as it had been seen first in Western, then Southern Europe, has also reached Central Europe. However, this modernisation follows a hierarchical spreading process, affecting large cities first, and lesser urban centres only gradually and - what is more remarkable - much more modestly. It is notable that advanced business services, with the highest effect on modernisation and prosperity, are also the most concentrated: this is confirmed by Gál (2005) on the example on banking; Horváth (2009) on R\&D, as well as this paper on advanced business services.

Finally, some outcomes of tertiarisation are best seen as not at all beneficial: in marginalised areas, a high share of service employment can be safely considered to conceal a lack, or destruction of other economic opportunities; instead of modernisation via entrepreneurship, the driving force is personal and collective survival. It is a striking manifestation of the problem that while the highest tertiary employment in Hungary is found in the capital, what follows afterwards is a succession of lagging or downright disadvantaged territorial units - on all scales of the NUTS hierarchy.

The unevenness of this restructuring has crucial spatial implications: structural correction should be understood as a universal and ultimately beneficial result of market transformation; modernisation and the more destructive manifestation of tertiarisation are meanwhile unevenly distributed and more ambiguous. As demonstrated by Figure 1, the degree of tertiarisation between the national economies of Central Europe does not correspond to development level - in fact, the reverse appears to be true, and differences emerge between a North-Western and a South-Eastern group. In this respect, the countries that have been most successful at retaining a high level of industrial employment - via the successful adaptation of indigenous industry, but mostly reindustrialisation through the attraction of FDI (c.f. Barta-Kukely, 2008) and advantageous institutional milieus that also encourage labour market flexibility (Póla, 2009, Gulyás, 2008) - have benefited more from transformation than the ones that have not. 


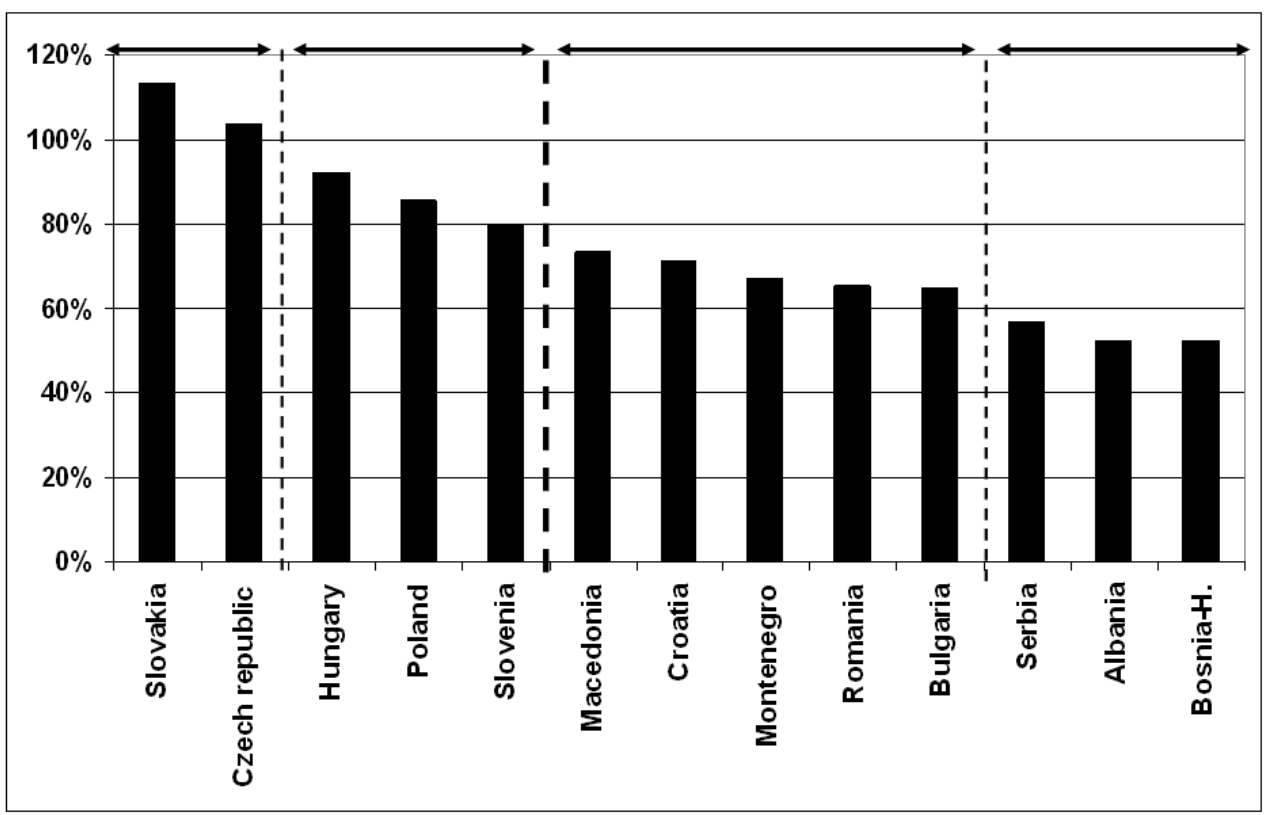

Fig. 1. Change in industrial employment in post-socialist economies, 1990-2008 (\%)

Source: Author's construction based on national statistical yearbooks and EUROSTAT

A similar conclusion can be drawn from sub-national data (Figure 2): on the regional level, there has been a change in the relationship between industrial employment and economic development: in 1990, it was the regions of the South-Eastern states that had the highest share of employment in industry due to extensive catch-up efforts, but this development masked severe qualitative deficiencies. The situation strongly altered by 2008: what becomes visible is a recreation of traditional (historical) industrial heartlands, with the new manufacturing core of Central Europe occupying a position eerily similar to the Łódz-Erfurt-Budapest triangle - a major concentration of industrial employment and the most competitive enterprises that could be observed going back to the pre-WW I period (Enyedi, 1978). If we break down the picture into industrial branches, the picture is similar - light and food industries (groups DA-DE under NACE classification) are primarily located in South-Eastern states and Eastern peripheral regions (especially in Poland); meanwhile, the most developed branches of machine industry (NACE DK-DN) are concentrated in the core industrial area (for the specific example of automotive industry, see Lefilleur, 2008 and Pavlínek-Domański-Guzik, 2009). Moreover, this area also encompasses 17 of the 25 most developed regions of Central Europe based on nominal GDP per capita: altogether, in this "top list", seven positions are taken by national capitals with predominantly service-based economies, but elsewhere, the contenders are mainly industrial with a high prevalence of Foreign Direct Investment. 

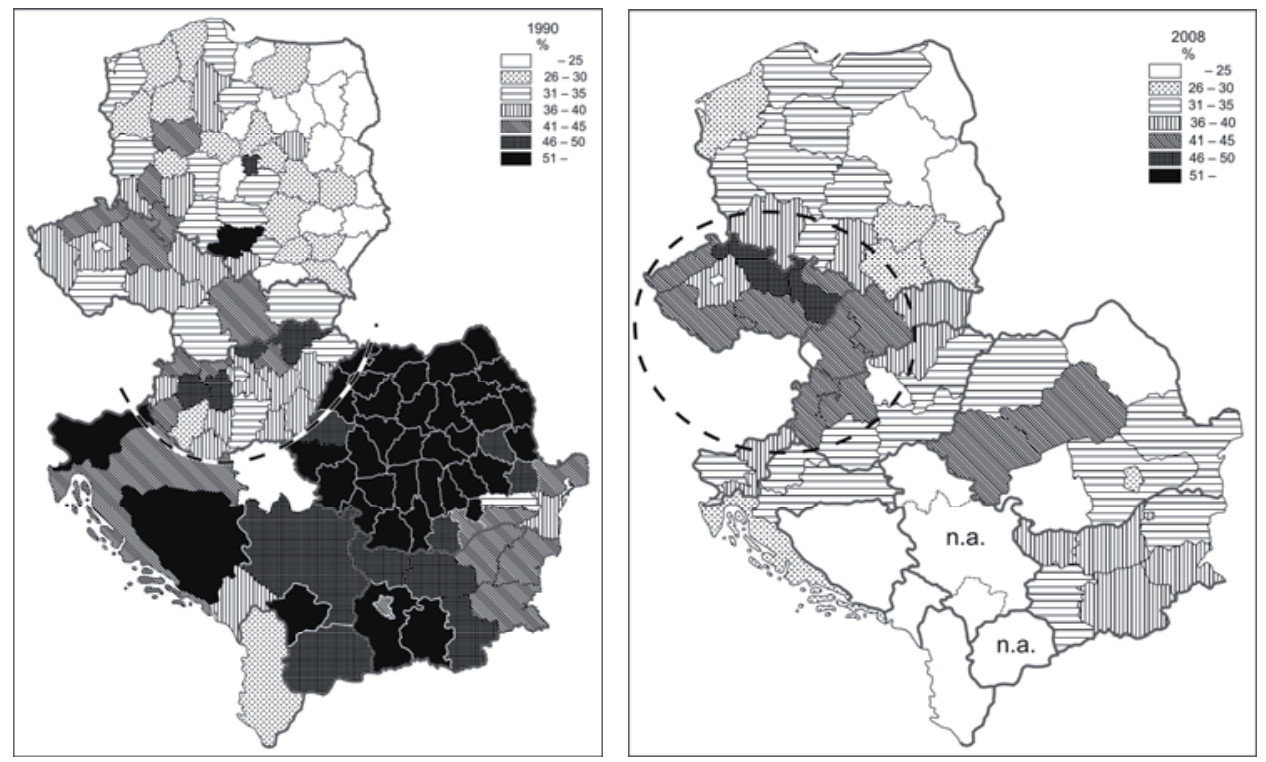

Fig. 2. The spatial structure of industrial employment, 1990 and 2008 (\%)

Source: Author's construction based on national statistical yearbooks and EUROSTAT

With respect to the location of advanced business services, (financial intermediation, real estate, renting and business activities; NACE J-K), they correspond closely to the urban hierarchy and are disproportionately located in central regions ${ }^{1}$ : the degree is $61 \%$ in Slovenia and Slovakia, 57\% in Bulgaria, 56\% in Hungary, 51\% in Croatia, $42 \%$ in the Czech Republic, $39 \%$ in Romania and only 23\% in Poland. The proportion is higher in states with a more monocentric urban network, less in the Czech Republic with Brno as a weak secondary pole, and somewhat more evenly distributed in relatively polycentric Romania and Poland (it is a telling indicator that four large banks maintain independent centres in the Upper Silesian region alone, while this would be unthinkable in most other countries). The uneven distribution of business services also has implications for the economic benefits of industry: even when manufacturing activities are distributed in a somewhat decentralised manner, the services tied to them - management, research, financial services etc. - are often located off-site in large urban centres, if not out of the country altogether.

The dichotomy of services and industry: sectoral and spatial components in economic differentiation

In this section of the paper, the previous questions of industrial and tertiary growth are examined on the basis of cross-sectional data. It is vital to know how different economic sectors contribute to economic development and if these contributions can be measured; maybe even more so whether their effect influences differentiation across space, between individual countries as well as on the sub-national level.

1 From here on, for the sake of comparability, the term "central region" is used to refer to national capitals as well as their immediate surroundings - i.e. Mazowieckie and Central Hungary, but Prague plus Central Bohemia and Bratislava plus Western Slovakia etc. 
To make a broad comparison possible, a correlation analysis of sectoral employment with per capita nominal GDP as a \% of the EU-27 average was undertaken across postsocialist Central Europe with a database of 55 regions (for lack of up-to-date sub-national data, Serbia was omitted from the analysis, along with Montenegro, Albania and BosniaHerzegovina). Data for employment was available for 2007-2008, while for GDP, 2006 figures were used. To examine whether there would be identifiable centre-periphery relationships in the spatial structure of industry, separate calculations were made for different categories. First, a distinction was made on a geographic basis between a North-Western and South-Eastern group of countries (c.f. Figure 1) to see if a relevant North-West-South-East difference existed. Second, sub-national differences were also examined with differentiation between central regions (as defined in Footnote 1) and non-central regions. The results are summarised in Table 1.

Tab. 1. Correlation between the share of sectoral employment (2007-2008) and per capita nominal GDP (2006)

\begin{tabular}{lccc}
\hline Region & $\begin{array}{l}\text { Agriculture, Forestry } \\
\text { and Fisheries } \\
\text { (NACE A - B) }\end{array}$ & $\begin{array}{l}\text { Industry and } \\
\text { Construction } \\
\text { (NACE C - F) }\end{array}$ & $\begin{array}{l}\text { Services } \\
\text { (NACE G - Q) }\end{array}$ \\
\hline All regions & -0.48 & -0.16 & $\mathbf{0 . 6 4}$ \\
North-Western group & -0.48 & -0.22 & $\mathbf{0 . 7 0}$ \\
South-Eastern group & -0.31 & -0.26 & 0.46 \\
\hline Non-central regions & -0.47 & 0.42 & 0.30 \\
North-Western group & -0.49 & $\mathbf{0 . 7 1}$ & -0.10 \\
South-Eastern group & -0.10 & -0.14 & 0.21 \\
\hline Central regions & -0.62 & -0.58 & 0.76 \\
\hline
\end{tabular}

Source: Author's construction based on national statistical yearbooks and EUROSTAT

Looking at the final results, it is visible that both centre-periphery relationships exist, but sub-national differences are more relevant than a North-West-South-East split. Globally, employment in services has a moderate positive correlation with the level of economic development (more so in the North-West), the role of industry and construction is ambiguous with a weak negative correlation, while agriculture is still tied to traditional underdevelopment. If we remove central regions from our calculations, however, the perspective changes: industry becomes the main contributor to development in the North-Western group, and the modernisation effect of services seems to be very modest, or even exhausted. The difference between North-West and South-East is a difference in growth potential: the FDI-transformed industrial landscape of the North-West is already a strong engine of growth (and it is the author's considered opinion that this has not been fundamentally altered by the 2008 crisis - not in the long term), while that of the South-East is still before important structural changes and an inflow of investments that would turn it into the same. Finally, the previously discussed concentration of the most competitive services contributes to the growth of central regions: they have moved strongly towards a post-industrial economy, although the positive effects of a select few industries - publishing, fine mechanics and various knowledge-intensive groups - can be measured in their case as well. 
A further analysis of results was possible via the finer break-down of employment data for industry (although, due to the availability of sub-national data, only the North-Western group could be included): confirming previous hypotheses, employment in machine industry (NACE DK-DN, especially electrical, optical and transport equipment) showed a moderate positive correlation (0.6) in non-central regions and a very weak negative one (-0.1) in central ones. Conversely, the values for food and light industry (NACE DA-DE) were -0.6 and 0.3 , respectively (with DE, paper, printing and publishing at 0.8 in the central group!).

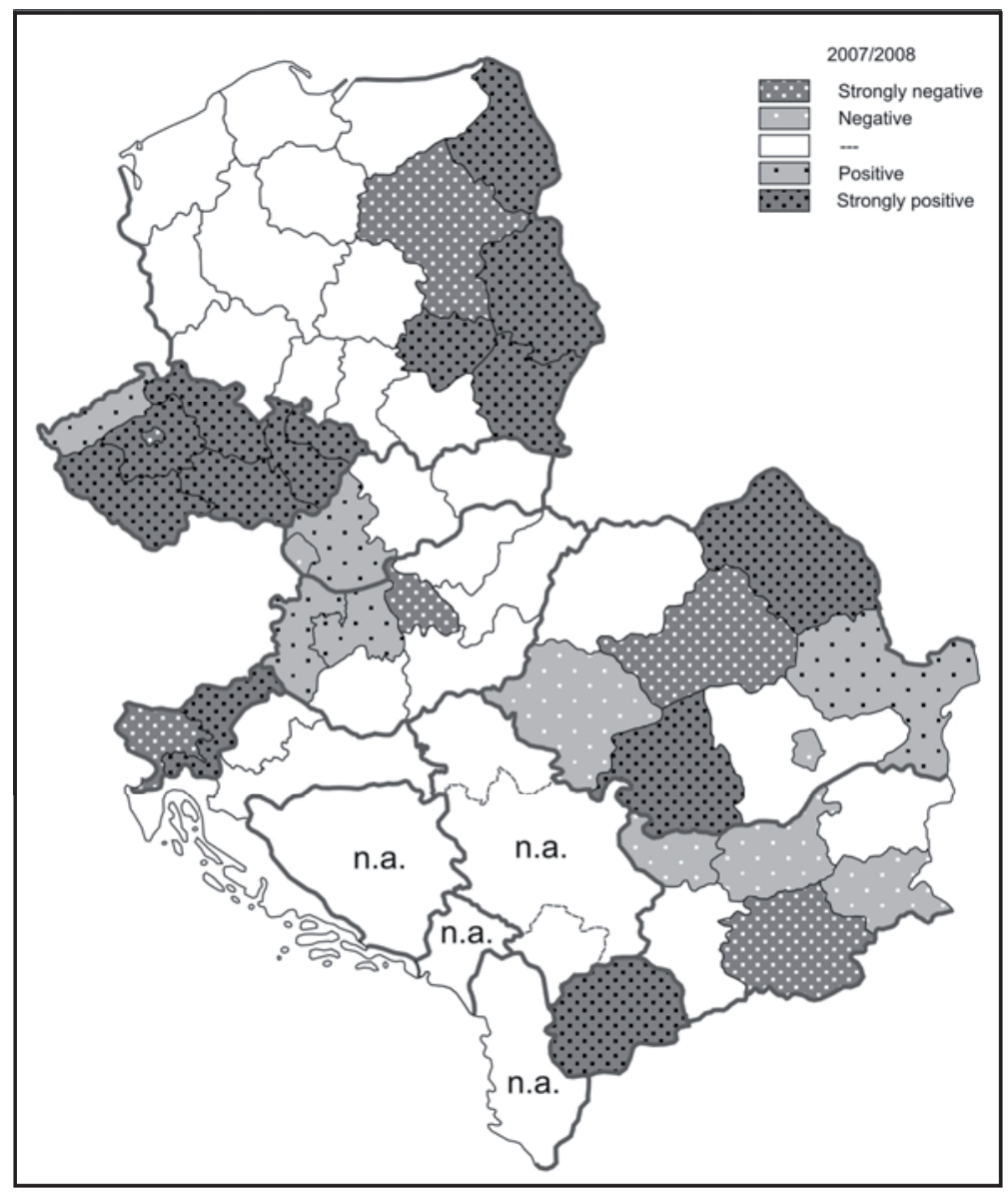

Fig. 3. Regional correlation between the share of industrial employment (2007/2008) and per capita nominal GDP (2006)

Source: Author's construction based on national statistical yearbooks and EUROSTAT

In an attempt to draw further conclusions, the degree of correlation was also examined on the regional level (Figure 3). Since correlation analysis is not possible for individual data points, values were instead determined by testing how the removal of data points would influence the correlation coefficient for the remaining dataset. These were then placed on a five-step scale indicating the direction and degree of correlation. Again, results showed a con- 
firmation of previous hypotheses: in the North-Western group, regions in Central Europe's core industrial area showed positive, often strongly positive correlation while the case was opposite in central regions; to the southwest, the picture was more varied. However, there is also something that may be a glimmer of hope to some peripheral regions - in Eastern Poland and Romania's less developed regions, positive correlation can be seen between industrial employment and economic development. It may be assumed, although currently without statistical evidence, that food industry and some light industrial traditions are the cause.

\section{DiSCUSSION}

Summing up the paper's points, the conclusion can be drawn that the role of services and industry in economic development has altered between 1990 and 2008. The observation that the development of the service economy would lead to prosperity had a case going for it at the time of transition, and also reflected a criticism of one-sided socialist development policies. Today, the old adage that the development opportunities for Central European economies lie in services has to be re-evaluated. Services have indeed become the main source of employment all over Central Europe - but not the sole, or even the main providers of growth. Regions without a high level of urbanisation often cannot properly take advantage of the highest dividends of the post-industrial economy, as the "best" results of service-based development show strong agglomeration tendencies. If we take into account the potential of industry, predominantly machine industry, a proper focus on both the qualitative and quantitative aspects of industrial development may serve as a means to achieve a more diversified and competitive economy, as well as better balanced territorial development.

\section{References}

Audretsch, D. B., Carree, M. A., van Stel, A. J., Thurik, A. R., 2000, Impeded industrial restructuring. The growth penalty. Tinbergen Institute, Amsterdam.

Barta, Gy, Kukely, Gy., 2008, Re-industrialisation in the world and in Hungary, European Spatial Research and Policy, No. 2, pp. 5-26.

Enyedi, Gy., 1978, Kelet-Közép-Európa gazdaságföldrajza. [The economic geography of Eastern Central Europe]. Közgazdasági és Jogi Könyvkiadó, Budapest.

Faragó, L., 2004, The general theory of public (spatial) planning. The social technique for creating the future. Discussion Papers No. 43. Centre for Regional Studies, Pécs.

Gál, Z., 2005, The development and the polarised spatial structure of the Hungarian banking system in a transforming economy, [in:] Barta, Gy., G. Fekete, É., Kukorelli Szörényiné, I., Timár, J. eds., Hungarian spaces and places: Patterns of transition. Centre for Regional Studies, Pécs, pp. 197-219.

Grabher, G., 1993, The weakness of strong ties. The lock-in of regional development in the Ruhr area. [in:] Grabher, G. ed., The embedded firm. On the socioeconomics of industrial networks. Routledge, London, pp. 255-277.

Guerrieri, P., 1998, Trade patterns, Foreign Direct Investment, and industrial restructuring of Central and Eastern Europe. [in:] Zysman, J., Schwartz, A. eds., Enlarging Europe: The industrial foundations of a new political reality. University of California at Berkeley, Berkeley, pp. 130-156.

Gulyás, L., 2008, Sustainable growth in the labour market, European attempts for reducing unemploy- 
ment, Annals of the Faculty of Economics, No 19. Novi Sad University Faculty of Economics, Novi Sad.

Horváth, Gy., 2009, Cohesion deficiencies in Eastern and Central Europe - Inequalities of regional research area. Discussion Papers No. 72. Centre for Regional Studies, Pécs.

Hudson, R., 1994, Institutional change, cultural transformation and economic regeneration: Myths and realities from Europe's Old Industrial Areas. [in:] Amin, A., Thrift, N. eds., Globalization, institutions, and regional development in Europe. Oxford University Press, Oxford, pp. 198-216.

Kornai, J., 1993, Transzformációs visszaesés. Egy általános jelenség vizsgálata a magyar fejlődés példáján. [Transformation recession. Examination of a general phenomenon on the example of Hungarian development.], Közgazdasági Szemle No. 7-8, pp. 569-599.

Lefilleur, J., 2008, Geographic reorganisation of the European automobile sector. What role for the Central and East European countries in an enlarged European Union? An empirical approach, Eastern European Economics, No. 5, pp. 69-91.

Pavlínek, P., Domański, B., Guzik, R., 2009, Industrial upgrading through Foreign Direct Investment in Central European automotive manufacturing, European Urban and Regional Studies, No. 1, pp. 43-63.

Póla, P., 2009, Az újraiparositás intézményi feltételei. [The institutional conditions of reindustrialisation]. [in:] Fodor, I., ed., A régiók újraiparositása. A Dél-Dunántúl esélyei. MTA Regionális Kutatások Központja, Pécs, pp. 69-78.

Soós Károly, A., 2002, Az átmeneti gazdaságok EU-exportja nemzetközi összehasonlitásban, 19932000. [The EU export of transition economies in international comparison, 1993-2000], Közgazdasági Szemle, No. 12., pp. 1063-1080.

Steiner, M., 1985, Old Industrial Areas: A theoretical approach, Urban Studies, No. 5, pp. 387-398.

Winiecki, J., 1986, Az ipar túlméretezettsége a kelet-európai szocialista országokban: tények, okok, következmények. [The oversized industry in Eastern European socialist states: Facts, causes and consequences], Közgazdasági Szemle, No. 5, pp. 579-592.

\section{Location differences of services and industry: A Central European dichotomy}

In post-socialist spatial restructuring, over-industrialised economies experienced a period of intense tertiarisation and the decline of industrial employment. However, the role of services in this process shows strong sectoral and spatial differences. In addition to structural correction, tertiarisation may be interpreted as the bearer of economic modernisation, but also a symptom of weakness where services dominate due to an absence of economic alternatives. Advanced business services are strongly concentrated in central regions, while elsewhere economic growth is still mainly driven by industry, whose location shows high path-dependency going back to the quantitative and qualitative factor supply, as well as a broader societal and institutional background that encourages the reproduction of industrial milieus.

Using empirical evidence from Central and South-Eastern European countries, the author examines how the sub-national location differences of services and industry reshape and recreate the region's traditional centre-periphery differences: evidence points to differentiation between not only central and non-central regions, but also the Central and South-Eastern European group of new EU members and candidate states.

Gabor Lux, Ph.D.

Hungarian Academy of Sciences Centre for Regional Studies, Pécs

e-mail: lux@rkk.hu 